\title{
NÁVRHY DE LEGE FERENDA VZŤAHUJÚCE SA NA REGULÁCIU FINANČNÉHO PORADENSTVA
}

\author{
PROPOSALS DE LEGE FERENDA RELATING \\ TO THE REGULATION OF FINANCIAL ADVISORY
}

\author{
Andrea Slezáková ${ }^{1}$ \\ Ekonomická univerzita v Bratislave \\ https://doi.org/10.33542/SIC2020-1-08
}

\begin{abstract}
ABSTRAKT
Niektorí účastníci finančného trhu (najmä finanční spotrebitelia) nie sú schopní relevantne vyhodnotit' úroveň bezpečnosti hospodárenia subjektov finančného trhu - podnikatel'ov. Súvisi to s nizkou mierou informovanosti, resp. nepochopením podstaty sofistikovaných finančných produktov, ponúkaných finančnými inštitúciami. Za účelom zmiernenia disproporcií v úrovni informácii, ktorými disponujú klienti a finančné inštitúcie zakotvuje štát v právnych predpisoch ochranu spotrebitel'a na finančnom trhu, ktorá sa odzrkadluje predovšetkým v diapazóne informačných povinností finančných inštitúcií voči klientom. V praxi majú k lepšiemu pochopeniu zmluvy o poskytnutí finančnej služby prispiet' nielen informačné povinnosti, ale aj finančné poradenstvo. Príspevok je zameraný na úvahy a návrhy de lege ferenda vztahujúce sa na reguláciu finančného poradenstva.
\end{abstract}

\begin{abstract}
Some participants on the financial market (in particular financial consumers) are not able to adequately assess the level of safety of the financial market entities - entrepreneurs. This is due to the low level of information, respectively due to the misunderstanding of the nature of sophisticated financial products offered by financial institutions. In order to mitigate the disproportions in the level of information available to clients and financial institutions, the state enshrines in the legislation consumer protection on the financial market, which is primarily reflected in the diapason of financial institutions' information obligations to their clients. In practice, not only information obligations, but also financial advisory should contribute to a better understanding of the financial service contract. The paper focuses on considerations and proposals de lege ferenda relating to the regulation of financial advisory.
\end{abstract}

\section{I. ÚVOD}

Dňa 1. januára 2020 uplynulo desat' rokov od nadobudnutia účinnosti zákona č. 186/2009 Z. z. o finančnom sprostredkovaní a finančnom poradenstve a o zmene a doplnení niektorých zákonov v znení neskorších predpisov (d’alej len ,zákon o finančnom sprostredkovaní a finančnom poradenstve"). Predmetný právny predpis ustanovil podmienky pre uskutočňovanie daných druhov podnikania. Zároveň zakotvil do slovenského právneho poriadku legálne definície pojmov finančného sprostredkovania a finančného poradenstva, z ktorých vyplýva nevyhnutnost' rozlišovania predmetných činností. V tomto kontexte uvádzame, že

Príspevok bol spracovaný v rámci projektu APVV-16-0553 „Premeny a inovácie konceptu kapitálových spoločností v podmienkach globalizácie“. 
najpodstatnejším znakom odlišujúcim finančné poradenstvo od finančného sprostredkovania je odplata, presnejšie zdroj odplaty. Kým finančný agent pri vykonávaní finančného sprostredkovania poberá odplatu od finančnej inštitúcie alebo od iného finančného agenta ${ }^{2}$, finančný poradca je ex lege povinný prijímat' akékol’vek peňažné alebo nepeňažné plnenie výlučne od klienta. ${ }^{3}$ Finančné poradenstvo možno uskutočňovat' na základe povolenia na vykonávanie činnosti finančného poradcu. ${ }^{4}$ Finančné poradenstvo predstavuje podnikanie poskytujúce klientovi výstup, ktorý má napĺnat' jeho požiadavky. ${ }^{5}$ Finančné poradenstvo je nerozlučne späté s nezávislým ohodnotením klienta alebo potenciálneho klienta a jeho potrieb vychádzajúcim $\mathrm{z}$ jeho finančných pomerov. ${ }^{6}$ Výstup činnosti finančného poradcu bude na základe vykonanej trhovej analýzy predstavovat' pre klienta odporúčanie najvhodnejšieho produktu. ${ }^{7}$ Finančný poradca je pre klienta činný na základe zmluvy o poskytnutí finančného poradenstva. Zmluva o poskytnutí finančného poradenstva predstavuje zmluvný typ zavedený zákonom, pre ktorú je ustanovená obligatórne písomná forma. ${ }^{8}$

\section{NÁVRHY DE LEGE FERENDA VZŤAHUJÚCE SA NA REGULÁCIU FINANČ- NÉHO PORADENSTVA}

Pojem regulácia finančného trhu obsahuje všetky tie normy, ktoré zahŕňajú úpravu správania sa aktérov finančného trhu, na základe príkazov a zákazov. Regulácia finančného trhu zabezpečuje taktiež predchádzaniu systémových rizík, vzhl'adom na dôležitost', ktorá prináleží finančnému sektoru v hospodárstve. ${ }^{9}$ Zároveň ňou štát plní jednu zo svojich funkcií, a to zaistenie stabilného a funkčného finančného trhu. ${ }^{10}$

Nevyhnutnost' regulácie vyplýva zo zlyhávania trhov, t. j. situácie, ked' už tieto nemôžu plnit' alokačnú funkciu, alebo ju neplnia efektívne. ${ }^{11}$ Štátny zásah do finančného sektora možno odôvodnit' existenciou externalít (externých efektov), ktoré vzniknú v prípade, ak má produkcia statkov alebo ponuka služieb vedl'ajší efekt na iné hospodárske subjekty a odzrkadl'uje sa v trhových cenách a tieto vedl'ajšie efekty nie sú znášané ich pôvodcom, ale tret'ou osobou, čím spôsobia negatívne externé náklady inej osoby, s ktorými táto ex ante nekalkulovala. ${ }^{12}$

Ďalším dôvodom pre zlyhávanie finančného trhu je informačná asymetria. Pod tento pojem možno subsumovat' všetky situácie, v ktorých jedna strana zmluvy o poskytnutí finančnej služby disponuje menším rozsahom informácií ako druhá. Spotrebitelia ako investori majú informačný deficit $\mathrm{v}$ porovnaní s finančnými inštitúciami, ked’že tieto disponujú presnými vedomost’ami o svojej finančnej situácii. ${ }^{13}$ Predmet činnosti finančnej inštitúcie je natol'ko

2 Porovnaj § 32 ods. 1 zákona o finančnom sprostredkovaní a finančnom poradenstve, podl’a ktorého finančný agent nesmie v súvislosti s vykonávaním finančného sprostredkovania prijímat' od neprofesionálneho klienta akékol’vek peňažné plnenie alebo nepeňažné plnenie.

3 Porovnaj § 32 ods. 5 zákona o finančnom sprostredkovaní a finančnom poradenstve.

4 Porovnaj § 18 ods. 1 zákona o finančnom sprostredkovaní a finančnom poradenstve. Zákonná úprava ustanovuje výnimky, porovnaj $\S 11, \S 11 \mathrm{a}$ a $\S 11 \mathrm{~d}$ zákona o finančnom sprostredkovaní a finančnom poradenstve.

5 BRANDL, E., SARIA, G.: Vom Finanzdienstleistungsassistenten zum Wertpapiervermittler: Anmerkungen zum Ministerialentwurf des BMF 264/ME 24. GP. In: Zeitschrift für Finanzmarktrecht. roč. 6, 2006, č. 3, s. 101- 105, s. 101.

6 HEROLD, M.: Finanzberatung gegen Provision oder Honorar : Eine Analyse aus Kundensicht mit Hilfe des PrinzipalAgent Ansatzes. München, Ravensburg: GRIN Verlag, 2004, s. 3.

7 SIDAK, M., SLEZÁKOVÁ, A. a kol.: Regulácia a dohl’ad nad činnostou subjektov finančného trhu. Bratislava : Wolters Kluwer, 2014, s. 205.

8 SIDAK, M., DURAČINSKÁ, M. a kol.: Finančné právo. 2. vydanie. Bratislava : C. H. Beck, 2014, s. 434.

9 LADLER, M., P.: Finanzmarkt und insitutionelle Finanzaufsicht in der EU. Wien : MANZ'sche Verlags- und Universitätsbuchhandlung, 2014, s. 124.

10 Tamže.

11 BALDWIN, R., CAVE, M., LODGE, M.: Understanding Regulation : Theory, Strategy and Practice. 2. vydanie. Oxford: Oxford University Press, 2012, s. 15.

12 MARQUARDT, J., C.: Financial Market Supervision : Some Conceptual Issues. Basle : BANK FOR INTERNATIONAL SETTLEMENTS, 1989, s. 6.

13 DAVIES, H., GREEN, D.: Global Financial Regulation: The Essential Guide. Cambridge : Polity Press, 2008 , s. 17. 
komplexný, že bez príslušného vzdelania ho môže pochopit' máloktorý klient. A ked’že získavanie informácií predstavuje náklady a zaberá čas, len minimum investorov sa informuje o jednotlivých finančných produktoch a finančných inštitúciách. ${ }^{14} \mathrm{~A}$ tu nastupuje úloha regulácie, ktorá stanovovaním informačných povinností redukuje informačnú asymetriu. Regulatórne prostredie ovplyvňuje aj kvalitu služieb, konkurencieschopnost' pre ich poskytovanie, zabezpečuje dostatočnú sút’až a zároveň ho charakterizuje, že v príslušnom sektore finančného trhu mu „vtláča svoju pečat"“ nielen národný, ale aj európsky zákonodarca.

\section{Smernica IDD}

Priamu novelu zákona o finančnom sprostredkovaní a finančnom poradenstve predstavuje zákon č. 282/2017 Z. z., ktorým sa mení a dopĺn̆a zákon č. 186/2009 Z. z. o finančnom sprostredkovaní a finančnom poradenstve a o zmene a doplnení niektorých zákonov v znení neskorších predpisov a ktorým sa mení a dopíňa zákon č. 39/2015 Z. z. o poist’ovníctve a o zmene a doplnení niektorých zákonov v znení neskorších predpisov (d’alej len „novela“). Novelou bola transformovaná smernica Európskeho parlamentu a Rady (EÚ) 2016/97 z 20. januára 2016 o distribúcii poistenia (prepracované znenie) ${ }^{15}$ (d’alej len ako „smernica IDD“).

Smernica IDD má za účel harmonizáciu národných predpisov vzt’ahujúcich sa na odbyt produktov poistenia a zaistenia klientom, ktorým má poskytnút’ jednotnú minimálnu úroveň ochrany nezávisle od toho aký odbytový kanál si zvolia. ${ }^{16}$ Smernica IDD nadobudla účinnost' dňa 23. februára 2016, členské štáty boli povinné ju transponovat' v priebehu 24 mesiacov, t. j. do 23. februára 2018. Bola výsledkom prvej úrovne legislatívneho Lamfalussyho procesu. Smernica IDD, tak ako vyplýva z jej názvu, reguluje distribúciu, nielen v ponímaní sprostredkovania, ale aj ako priamy odbyt. Dôvod prijatia danej právnej úpravy predstavovalo rovnaké zaobchádzanie so všetkými distribútormi poistenia. Ked’že ide o smernicu, ktorá nevyžaduje full-harmonisation, ale minimálnu harmonizáciu, bolo na členských štátoch, či za účelom ochrany spotrebitel'ov prijmú prísnejšiu reguláciu, pokial' táto bude súladná s primárnym a sekundárnym právom EÚ.

V súlade s článkom 10 smernice IDD: „Domovské členské štáty zabezpečia, aby distribútori poistenia a zaistenia a zamestnanci poist'ovní a zaist'ovní vykonávajúci činnosti distribúcie poistenia alebo zaistenia disponovali primeranými znalost'ami a schopnost'ami, aby mohli plnit' svoje úlohy a povinnosti.“ Na uvedené reflektoval zákonodarca novelizáciou $\S 18$ a $\S 21$ zákona o finančnom sprostredkovaní a finančnom poradenstve. Pozornost' zameriavame, v tomto kontexte, na reguláciu právneho inštitútu odbornej spôsobilosti, ktorého súčast'ou sú požiadavky na odbornú prax fyzických osôb zastávajúcich taxatívne vymedzené funkcie u finančného poradcu a zamestnancov finančného poradcu vykonávajúcich činnost', ktorej obsahom je finančné poradenstvo. Do 22. februára 2018, bola v právnom inštitúte odbornej spôsobilosti normovaná ako jeho nedelitel'ná súčast' odborná prax v oblasti finančného trhu. Pri vymedzení pojmu „oblast' finančného trhu“, bolo predovšetkým potrebné vychádzat' z dohliadacej funkcie Národnej banky Slovenska zakotvenej v $§ 2$ ods. 3 písm. a) zákona Národnej rady Slovenskej republiky č. 566/1992 Zb. o Národnej banke Slovenska v znení neskorších predpisov (d’alej len ,zákon o Národnej banke Slovenska“). Rovnako jej zákonný mandát udel'uje $\S 36$ zákona o Národnej banke Slovenska, ktorý hovorí o výkone dohl'adu nad finančným trhom v súlade s predmetným zákonom, ako aj s osobitnými sektorovými zákonmi. Jedným z nich je aj zákon č. 747/2004 Z. z. o dohl'ade nad finančným trhom a o zmene

\footnotetext{
DEWATRIPONT, M., TIROLE, J.: The Prudential Regulation of Banks. Cambridge, MA : The MIT Press, 1995, s. 31. Ú. v. EÚ L 26, 2.2.2016.

16 BERISHA, A., GISCH, E., KOBAN, K. a kol.: Haftpflicht-, Rechtsschutzversicherung und Versicherungsvertriebsrecht. Wien : MANZ'sche Verlags- und Universitätsbuchhandlung, 2018, s. 135.
} 
a doplnení niektorých zákonov v znení neskorších predpisov (d’alej len „zákon o dohl'ade nad finančným trhom“), ktorý v $\S 1$ ods. 3 písm. a) obsahuje enumeratívny ${ }^{17}$ výpočet dohliadaných subjektov finančného trhu. Z čoho vyplývalo, že odbornú prax na finančnom trhu bolo možné získat' v dohliadaných subjektoch finančného trhu. Podstatou právnej úpravy bola myšlienka, že ak osoba nadobudla odbornú prax v niektorom zo sektorov finančného trhu, napr. bola compliance officer u obchodníka s cennými papiermi, uvedená činnost' bola subsumovaná pod všeobecný pojem odbornej praxe na finančnom trhu a bola odborne spôsobilou aj vtedy, ak napríklad chcela začat' vykonávat' činnost' finančného poradcu v sektore poistenia alebo zaistenia. S účinnost'ou od 23. februára 2018, zákonodarca požaduje preukázanie praxe, ktorá sa vzt’ahuje na sektor, v ktorom má osoba záujem vykonávat' v budúcnosti finančné poradenstvo. Ide o odbornú činnost', ktorá je spojená s niektorým so sektorov - poistenia alebo zaistenia, kapitálového trhu, prijímania vkladov, poskytovania úverov, úverov na bývanie a spotrebitel'ských úverov, doplnkového dôchodkového sporenia alebo starobného dôchodkového sporenia. Vzniká povinnost' preukázat' prax, ktorá je špecifická a viazaná na niektorý z hore uvedených sektorov. V novom legislatívnom prostredí platí, že fyzická osoba, ktorá nadobudla odbornú prax u obchodníka s cennými papiermi ako compliance officer, na základe tejto skutočnosti môže preukázat' prax výlučne v sektore kapitálového trhu. V prípade, že by chcela vykonávat' finančné poradenstvo v sektore poistenia alebo zaistenia, daná odborná prax by bola bezpredmetná. Uvádzame, že sprísnenie vybraných zákonných ustanovení vzt’ahujúcich sa na vykonávanie finančného poradenstva ${ }^{18}$ považujeme za námet pre úvahy o d’alších návrhoch de lege ferenda.

\section{Návrh de lege ferenda - Predmet činnosti}

Právo finančného trhu možno považovat' za pododvetvie finančného práva úzko späté s obchodným právom. Pre podnikanie dohliadaných subjektov finančného trhu platí lex specialis derogat lex generalis. V tomto prípade všeobecnejšie obchodnoprávne normy ustupujú špeciálnejším finančnoprávnym normám. Osobitosti, ktoré vykazujú zákony regulujúce jednotlivé sektory finančného trhu sa odzrkadl'ujú predovšetkým v nárokoch, ktoré kladie zákonodarca na právnu formu obchodnej spoločnosti, na odbornú spôsobilost', ako aj počty členov štatutárneho orgánu príslušnej obchodnej spoločnosti. Vo všeobecnosti môžeme konštatovat', že spravidla ide o zvýšený počet členov štatutárneho orgánu v porovnaní s obchodnoprávnou úpravou, alebo o povinnost' spoločného konania minimálne dvoch členov štatutárneho orgánu a pod. Základnou zákonnou požiadavkou pre uskutočňovanie podnikania na finančnom trhu je získanie príslušného povolenia, licencie alebo iného individuálneho správneho aktu umožňujúceho realizáciu predmetu činnosti, ktorý môže byt' zákonodarcom zadefinovaný ako výlučný a ktorého zmena je zároveň ex lege zakázaná.

$\mathrm{Na}$ webovom sídle Národnej banky Slovenska je zverejnený zoznam subjektov, ktorým bolo udelené povolenie na vykonávanie činnosti finančného poradcu. Ide o 12 obchodných spoločností. Pričom všetky majú právnu formu spoločnosti s ručením obmedzeným. ${ }^{19} \mathrm{Na}$ základe analýzy údajov dostupných z obchodného registra, zist'ujeme, že predmetom činnosti daných obchodných spoločností je okrem iného najmä aj činnost' ekonomických a organizačných poradcov, faktoring a forfaiting, finančný lízing, kúpa tovaru na účely jeho predaja

\footnotetext{
17 Vychádzame zo skutočnosti, že osobitné sektorové právne predpisy zakotvujú dohl'ad Národnej banky Slovenska aj nad osobami vykonávajúcimi nepovolenú činnost', resp. nad osobami, ktorých obchody a postavenie súvisia s dohliadaným subjektom finančného trhu. Obdobne RÝDL, T., BARÁK, J., SAŇA, L., VÝBORNÝ, P.: Zákon o České národní bance. Komentár. Praha : Wolters Kluwer, 2014, s. 149.

18 Predovšetkým išlo o reguláciu odbornej spôsobilosti.

19 Zoznam subjektov, ktorým bolo udelené povolenie na vykonávanie činnosti finančného poradcu, je dostupný na webovom sídle Národnej banky Slovenska https://subjekty.nbs.sk/?aa=select_sector\&bb=6\&cc=\&qq= [cit. 31-12-2019].
} 
konečnému spotrebitel'ovi (maloobchod), kúpa tovaru za účelom jeho predaja iným prevádzkovatel'om živnosti (vel'koobchod), prieskum trhu a verejnej mienky, počítačové služby, prenájom nehnutel'ností spojený s poskytovaním iných než základných služieb spojených s prenájmom, prenájom hnutel'ných vecí, reklamné a marketingové služby, skladovanie, služby súvisiace $\mathrm{s}$ počítačovým spracovaním údajov, sprostredkovatel'ská činnost' v oblasti služieb, sprostredkovatel'ská činnost' v oblasti obchodu, vedenie účtovníctva. ${ }^{20} \mathrm{Z}$ čoho vyplýva, že ani u jednej z obchodných spoločností nepredstavuje vykonávanie finančného poradenstva v príslušnom sektore finančného trhu výlučný predmet činnosti. Pričom však výlučné vykonávanie regulovaného predmetu činnosti predstavuje jeden z príznačných znakov pre podnikanie dohliadaných subjektov finančného trhu. Ako príklad uvádzame dôchodkové správcovské spoločnosti a doplnkové dôchodkové spoločnosti. Podl'a $§ 47$ ods. 1 zákona č. 43/2004 Z. z. o starobnom dôchodkovom sporení a o zmene a doplnení niektorých zákonov v znení neskorších predpisov (d’alej len „zákon o starobnom dôchodkovom sporení“): „Dôchodková správcovská spoločnost' je akciová spoločnost' so sídlom na území Slovenskej republiky, ktorej predmetom činnosti je vytváranie a správa dôchodkových fondov na vykonávanie starobného dôchodkového sporenia podl'a tohto zákona, a to na základe povolenia na vznik a činnost' dôchodkovej správcovskej spoločnosti udeleného Národnou bankou Slovenska podl'a tohto zákona.“ Podl'a $\S 47$ ods. 5 prvej vety zákona o starobnom dôchodkovom sporení: „Dôchodková správcovská spoločnost' nesmie vykonávat' inú činnost', ako je činnost' podl'a tohto zákona." Obdobne v súlade s $§ 22$ ods. 1 zákona č. 650/2004 Z. z. o doplnkovom dôchodkovom sporení a o zmene a doplnení niektorých zákonov v znení neskorších predpisov (d’alej len ,zákon o doplnkovom dôchodkovom sporení“): „Doplnková dôchodková spoločnost’ je akciová spoločnost' so sídlom na území Slovenskej republiky, ktorej predmetom činnosti je vytváranie a správa doplnkových dôchodkových fondov na účel vykonávania doplnkového dôchodkového sporenia, a to na základe povolenia na vznik a činnost' doplnkovej dôchodkovej spoločnosti (d’alej len ,povolenie“) udeleného Národnou bankou Slovenska.“ Podl'a $§ 22$ ods. 5 prvej vety zákona o doplnkovom dôchodkovom sporení: „Doplnková dôchodková spoločnost' nesmie vykonávat' inú činnost', ako je činnost' podl'a tohto zákona.“

Dôvod pre predmetný návrh de lege ferenda predstavuje aj skutočnost', že zákonodarca osobitne upravuje kategóriu finančných poradcov ako nezávislých odborníkov a potreba zvýšenia nárokov na ich podnikanie $\mathrm{v}$ porovnaní s finančnými agentmi je odôvodnená ich vysokou mierou zodpovednosti pri uskutočňovaní predmetnej činnosti. Myšlienka sprísnenia regulácie vychádza z legitímnych očakávaní klientov. Ak fyzická, alebo právnická osoba uzatvorí zmluvu o poskytnutí finančného poradenstva, má za to, že za odplatu jej budú poskytnuté služby istej úrovne. Podstata finančného poradenstva spočívajúca na nezávislej analýze dostatočného počtu dostupných služieb v príslušnom sektore si vyžaduje vysoký stupeň špecializácie. Vychádzajúc $z$ danej myšlienky, máme za to, že je prípustné, aby finančné poradenstvo zákonodarca upravoval prísnejšie ako finančné sprostredkovanie a zakotvil striktnú požiadavku, že finančný poradca iný predmet činnosti ako je finančné poradenstvo uskutočňovat' nesmie.

Rovnako dôvodom pre legislatívne zakotvenie predmetného návrhu de lege ferenda je skutočnost', aby obchodná spoločnost', ktorá je zároveň dohliadaným subjektom finančného trhu nevykonávala vzájomne si konkurujúce predmety činnosti, čím by dochádzalo ku konfliktu záujmov. Pri rôznorodosti predmetov činnosti na vykonávanie ktorých sú oprávnení finanční poradcovia, v praxi nemožno vylúčit’ vznik konfliktu záujmov. A preto za najúčinnejší spôsob jeho predchádzania považujeme uloženie zákonnej povinnosti výlučnosti predmetu činnosti finančného poradenstva.

20 Porovnaj www.orsr.sk [cit. 31-12-2019]. 
Okrem slovenskej právnej úpravy poukazujeme aj na obdobné právne normy obsiahnuté v príslušných právnych predpisoch Českej republiky, podl'a ktorých „bankový“ obchodník s cennými papiermi môže vykonávat' iba činnosti uvedené v zákone č. 21/1992 Sb. o bankách v znení neskorších predpisov a činnosti vyhradené zákonom č. 256/2004 Sb. o podnikaní na kapitálovom trhu $\mathrm{v}$ znení neskorších predpisov v režime licencie obchodníka s cennými papiermi, pokial' vyplývajú z jeho povolenia. ${ }^{21}$

Reguláciu možno v najširšom slova zmysle definovat' aj ako o súbor právnych mechanizmov, prostredníctvom ktorých realizuje regulátor svoj vplyv na finančný trh, resp. na príslušný sektor finančného trhu a je na jeho úvahe aké nástroje zvolí, aby dosiahol vytýčený ciel'. Za ostatný dôvod pre daný návrh de lege ferenda považujeme už zo súčasnej právnej úpravy vyplývajúci najvyšší stupeň odbornej spôsobilosti, ktorý sú povinné dosiahnut' fyzické osoby, ktoré zastávajú taxatívne definovaný okruh funkcií. V súlade $\mathrm{s} \S 21$ ods. 8 zákona o finančnom sprostredkovaní a finančnom poradenstve povinnost' dosiahnut' najvy̌šsí stupeň má finančný poradca, ktorý je fyzickou osobou, štatutárny orgán alebo aspoň jeden člen štatutárneho orgánu finančného poradcu, ktorý je zodpovedný za vykonávanie finančného poradenstva a odborný garant finančného poradcu. Najvyšší stupeň odbornej spôsobilosti okrem iného predpokladá úroveň poznatkov a vedomostí o finančnom trhu, ktorá sa má kontinuálne prehlbovat'. Vzhl'adom na neustále sa zvyšujúcu sofistikovanost' zmlúv o poskytnutí finančnej služby, máme za to, že štúdium a nadobúdanie informácií, si vyžaduje plnohodnotné a výlučné zameranie predmetu činnosti obchodnej spoločnosti na vykonávanie finančného poradenstva.

\section{Návrh de lege ferenda - Predchádzajúci súhlas Národnej banky Slovenska}

Podnikanie na finančnom trhu je natol'ko špecifické, že si vyžaduje ingerenciu zo strany štátu, a to nielen pri začatí vykonávania činnosti, ale aj pri uskutočňovaní istých zákonnou úpravou taxatívne definovaných úkonov. Dohliadané subjekty finančného trhu sú povinné podnikat' v medziach zákonov regulujúcich ich činnost', ergo prijímajú všetky opatrenia nevyhnutné na dodržiavanie povinností.

Pri realizácii dohl’adu nad finančným trhom, Národná banka Slovenska okrem iného vedie povol'ovacie konania. Ich účelom je udel'ovanie povolení, licencií, predchádzajúcich súhlasov Národnej banky Slovenska, súhlasov Národnej banky Slovenska alebo iných rozhodnutí umožňujúcich začatie vykonávania činnosti na finančnom trhu alebo vykonanie právnych úkonov. Predchádzajúci súhlas Národnej banky Slovenska je podmienkou na vykonanie taxatívne definovaného okruhu úkonov určených osobitnými zákonmi. V povol’ovacom konaní, Národná banka Slovenska na základe dôkazných prostriedkov predložených účastníkom konania porovnáva predpoklady, ktoré žiadatel' o vykonanie príslušného úkonu vytvoril, so zákonnými podmienkami zakotvenými v osobitnom právnom predpise. Či došlo k naplneniu zákonných požiadaviek vyjadrí Národná banka Slovenska rozhodnutím vo veci, ktorým udelí alebo neudelí svoj predchádzajúci súhlas na vykonanie príslušného úkonu.

Z hl'adiska vedenia povol'ovacích konaní vykazuje uskutočňovanie finančného poradenstva spoločný prvok s podnikaním iných dohliadaných subjektov, a to ingerenciu zo strany Národnej banky Slovenska pri začatí vykonávania činnosti. Ako už bolo uvedené, finančné poradenstvo možno uskutočňovat' výlučne na základe povolenia na vykonávanie činnosti finančného poradcu udel'ovaného Národnou bankou Slovenska. Ide o právnu úpravu spätú s myšlienkou, že finančné poradenstvo sú oprávnené realizovat' výlučne subjekty, ktoré preukázali splnenie zákonných podmienok pre udelenie príslušného povolenia v povol'ovacom

${ }^{21}$ HUSTÁK, Z., ŠOVAR, J., FRANĚK, M., SMUTNÝ, A., CETLOVÁ, K., DOLEŽALOVÁ, D.: Zákon o podnikání na kapitálovém trhu. Komentár. Praha : C. H. Beck, 2012, s. 110. 
konaní. Osobitné právne predpisy vzt’ahujúce sa na jednotlivé sektory finančného trhu obsahujú obdobnú reguláciu (napr. podl'a $§ 2$ ods. 1 prvej vety zákona č. 483/2001 Z. z. o bankách a o zmene a doplnení niektorých zákonov v znení neskorších predpisov: „Banka je právnická osoba so sídlom na území Slovenskej republiky založená ako akciová spoločnost', ktorá je úverovou inštitúciou podl'a osobitného predpisu a ktorá má bankové povolenie.“; v súlade

s § 54 ods. 1 zákona č. 566/2001 Z. z. o cenných papieroch a investičných službách a o zmene a doplnení niektorých zákonov (zákon o cenných papieroch) v znení neskorších predpisov (d’alej len „zákon o cenných papieroch“): „Obchodníkom s cennými papiermi je akciová spoločnost' so sídlom na území Slovenskej republiky, ktorej predmetom činnosti je poskytovanie investičných služieb klientom alebo výkon investičných činností na základe povolenia na poskytovanie investičných služieb udeleného Národnou bankou Slovenska.").

V porovnaní s osobitnými právnymi predpismi z iných sektorov finančného trhu, $\mathrm{v}$ zákone o finančnom sprostredkovaní a finančnom poradenstve absentuje právna úprava predchádzajúceho súhlasu Národnej banky Slovenska.

Predchádzajúci súhlas Národnej banky Slovenska je individuálnym správnym aktom, ktorým Národná banka Slovenska umožňuje vykonanie úkonu, a to na základe a v rozsahu žiadosti dohliadaného subjektu finančného trhu, ktorý preukázal v konaní vo veciach dohl'adu splnenie zákonne ustanovených podmienok pre jeho udelenie. Účelom udel'ovania predchádzajúcich súhlasov Národnej banky Slovenska je predovšetkým monitorovanie uskutočňovania predmetu činnosti dohliadaného subjektu finančného trhu a kontinuálneho plnenia podmienok pre udelenie príslušného povolenia. Z osobitných zákonov vyplýva, že do okruhu úkonov podliehajúcich predchádzajúcemu súhlasu Národnej banky Slovenska možno predovšetkým zaradit' nadobudnutie kvalifikovanej účasti na dohliadanom subjekte finančného trhu, zníženie základného imania dohliadaného subjektu finančného trhu, zmena sídla dohliadaného subjektu finančného trhu, predaj podniku dohliadaného subjektu finančného trhu, vol'bu osôb navrhovaných za členov štatutárneho alebo dozorného orgánu dohliadaného subjektu finančného trhu, zlúčenie, splynutie, rozdelenie dohliadaného subjektu finančného trhu a vrátenie príslušného povolenia. Vykonanie právneho úkonu bez predchádzajúceho súhlasu Národnej banky Slovenska je spojené s absolútnou neplatnost'ou ${ }^{22}$, teda neplatnost'ou, ktorá nastáva ex lege.

Rovnako je neplatný právny úkon uskutočnený na základe predchádzajúceho súhlasu Národnej banky Slovenska udeleného na základe nepravdivých údajov. ${ }^{23}$ Máme za to, že v záujme konzistentnosti regulácie na celom finančnom trhu ${ }^{24}$ sa ako potrebné javí inkorporovat' právny inštitút predchádzajúceho súhlasu Národnej banky Slovenska aj do zákona o finančnom sprostredkovaní a finančnom poradenstve. Úkony, u ktorých máme za to, že by mali podliehat' predchádzajúcemu súhlasu Národnej banky Slovenska, sú nadobudnutie kvalifikovanej účasti na finančnom poradcovi, predaj podniku finančného poradcu, vol'ba osôb navrhovaných za členov štatutárneho orgánu finančného poradcu, odborného garanta finančného poradcu alebo dozorného orgánu finančného poradcu a vrátenie povolenia na vykonávanie činnosti finančného poradcu. Návrh de lege ferenda zdôvodňujeme aj tým, že v súčasnosti je kontinuálne plnenie podmienok pre udelenie povolenia na vykonávanie činnosti finančného

22 Ibaže osobitný zákon ustanoví inak. Napr. podl’a § 52 ods. 13 zákona o starobnom dôchodkovom sporení: „Neplatné sú úkony, na ktoré sa podl’a tohto zákona vyžaduje predchádzajúci súhlas Národnej banky Slovenska, ak boli vykonané bez tohto predchádzajúceho súhlasu s výnimkou uvedenou v odseku 1 písm. a).“

23 Porovnaj napr. $§ 159$ ods. 3 druhú vetu zákona o cenných papieroch.

24 Predchádzajúcemu súhlasu Národnej banky Slovenska podliehajú v zákonne ustanovenom rozsahu právne úkony bánk, poist'ovní, zaist'ovní, obchodníkov s cennými papiermi, dôchodkových správcovských spoločností, doplnkových dôchodkových spoločností či správcovských spoločností. 
poradcu monitorované aj na základe informačných povinností voči Národnej banke Slovenska. Idea zavedenia predchádzajúcich súhlasov Národnej banky Slovenska do právnej úpravy na finančnom trhu vychádza zo skutočnosti, že správanie v súlade s osobitnými právnymi predpismi je potrebné i vynucovat'. Plnenie informačných povinností predstavuje v porovnaní s povol'ovacím konaním, podl'a nášho názoru, menej efektívny nástroj postavený na monitorovaní ex post, kým predchádzajúci súhlas Národnej banky Slovenska umožňuje orgánu dohl'adu zasiahnut' ex ante, t. j. ešte pred vykonávaním úkonu (napr. vol'bou fyzickej osoby za člena štatutárneho orgánu finančného poradcu, ktorá nie je odborne spôsobilá). Zavedenie právneho inštitútu predchádzajúceho súhlasu Národnej banky Slovenska pre taxatívne určený okruh úkonov uskutočňovaných finančným poradcom je možné zdôvodnit' aj skutočnost'ou, že i napriek tomu, že finančný poradca nehospodári s aktívami klienta, jeho odporúčanie môže mat' významný dosah na finančnú situáciu klienta, osobitne berúc na zretel' neprofesionálneho klienta. Pri úvahe de lege ferenda o zavedení predchádzajúcich súhlasov Národnej banky Slovenska sme vychádzali taktiež zo skutočnosti, že zákonodarca pripúšt’a rozdiely pri uskutočňovaní dohl'adu nad jednotlivými kategóriami finančných agentov. Dohl'ad nad vykonávaním finančného sprostredkovania samostatným finančným agentom realizuje Národná banka Slovenska. Zároveň zákon o finančnom sprostredkovaní a finančnom poradenstve ustanovuje istú formu dohl'adu navrhovatel'a - finančnej inštitúcie, resp. samostatného finančného agenta nad ich podriadenými subjektmi. Hovoríme o prenesenom/delegovanom dohl'ade Národnej banky Slovenska na navrhovatel'a. ${ }^{25}$ Nepôjde o dohl'ad Národnej banky Slovenska, ale o aktivitu podnikatel'a, ktorý bude dohliadat' na podnikanie iného podnikatel'a a sám bude dohliadaný ako túto povinnost' plní zo strany Národnej banky Slovenska. Táto zákonná konštrukcia je nevyhnutá, pretože pri súčasnom počte podriadených a viazaných finančných agentov, je z kapacitných dôvodov nemožné, aby boli dohliadaní Národnou bankou Slovenska. Zdôrazňujeme, že ani podriadení, ani viazaní finanční agenti nepatria medzi dohliadané subjekty finančného trhu. Za zákonných podmienok im však v súlade so zákonom o finančnom sprostredkovaní a finančnom poradenstve bude udelená sankcia. Z čoho vyplýva, že je odlišný diapazón subjektov, ktoré Národná banka Slovenska dohliada a ktoré je oprávnená sankcionovat'. Medzi jednotlivými kategóriami finančných agentov zákonodarca týmto vytvára rozdiely a ak je prípustné rozlišovanie medzi subjektami uskutočňujúcimi rovnaký druh podnikania, javí sa ako potenciálne možné, aby podrobil finančných poradcov d’alším zákonným povinnostiam.

\section{Návrh de lege ferenda - Pripravenost' na vykonávanie činnosti}

Zákon o dohl'ade nad finančným trhom v tretej časti upravuje konanie vo veciach dohl'adu v rámci, ktorého Národná banka Slovenska uskutoční miestnu obhliadku, ak je to potrebné pre rozhodnutie vo veci. ${ }^{26}$ Zo zákona č. $492 / 2009$ Z. z. o platobných službách a o zmene a doplnení niektorých zákonov v znení neskorších predpisov (d’alej len „zákon o platobných službách“) vyplýva pre Národnú banku Slovenska povinnost’ uskutočnit’ miestnu obhliadku. A to vzhl'adom na skutočnost', že v povol'ovacom konaní je povinná preverit', pred udelením povolenia na poskytovanie platobných služieb, pripravenost’ žiadatel'a na vykonávanie tohto druhu podnikania. ${ }^{27}$ Ide teda o povinnost' uskutočnit' miestnu obhliadku vyplývajúcu $\mathrm{z}$ hmotnoprávneho predpisu ešte pred udelením príslušného povolenia.

\footnotetext{
25 ČUNDERLÍK, L'. a kol.: Právo finančného trhu. Bratislava : Wolters Kluwer, 2017, s. 147. Obdobne KRAVECOVÁ, D.: Finančné sprostredkovanie. Ako podnikat' legálne. Bratislava : IURIS LIBRI, 2016, s. 152.

26 Porovnaj § 17 ods. 5 zákona o dohl’ade nad finančným trhom.

27 Porovnaj § 64 ods. 8 zákona o platobných službách podla ktorého: „Žiadatel', ktorý chce byt' platobnou inštitúciou, je pred udelením povolenia podl'a odseku 1 povinný preukázat' Národnej banke Slovenska technickú, organizačnú a perso-
} 
Reguláciu preverenia pripravenosti na vykonávanie predmetu činnosti povoleného Národnou bankou Slovenska obsahuje aj zákon o cenných papieroch. Odlišný je však časový okamih zist'ovania pripravenosti. Kým podl'a zákona o platobných službách, postupuje Národná banka Slovenska v konaní vo veciach dohl'adu a ešte pred vydaním rozhodnutia zist'uje na miestnej obhliadke pripravenost' žiadatel'a, zákon o cenných papieroch upravuje zist'ovanie pripravenosti na výkon povolených činností ex post. Ide o okamih, kedy bolo žiadatel'ovi už udelené povolenie na poskytovanie investičných služieb, avšak faktické začatie činnosti ešte možné nie je. ${ }^{28} \mathrm{~V}$ súlade s $\S 55$ ods. 7 zákona o cenných papieroch s výkonom činností uvedených $\mathrm{v}$ povolení na poskytovanie investičných služieb môže obchodník s cennými papiermi začat' až na základe písomného oznámenia Národnej banky Slovenska o splnení technickej, organizačnej a personálnej pripravenosti na výkon povolených činností. Máme za to, že v porovnaní so zákonom o platobných službách, už Národná banka Slovenska neuskutočňuje miestnu obhliadku podl'a zákona o dohl'ade nad finančným trhom. Konanie vo veciach dohl'adu je v čase preverovania pripravenosti obchodníka s cennými papiermi už právoplatne ukončené, a preto nemožno postupovat' podl'a tretej časti zákona o dohl'ade nad finančným trhom. Máme za to, že postupuje výlučne podl'a hmotnoprávneho predpisu, ktorým je zákon o cenných papieroch.

Oba osobitné zákony spája idea preverenia pripravenosti subjektu, počas ktorého sa simuluje poskytovanie služieb $\mathrm{v}$ rozsahu, ktorý bol povolený. Z platnej právnej úpravy vyplýva, že u žiadatel'a, ktorý zamýšl’a vykonávat' finančné poradenstvo, je preskúmavaná personálna, technická aj organizačná pripravenost' na realizáciu daného podnikania. ${ }^{29}$ A to na základe listinných dôkazov predložených účastníkom konania. ${ }^{30} \mathrm{Z}$ hl'adiska zvýšenia miery ochrany klientov budúcich finančných poradcov sa ako vhodné javí preverit' ich pripravenost' na vykonávanie predmetnej činnosti. ${ }^{31} \mathrm{~V}$ praxi by bolo preverovanie zamerané na simulované poskytnutie služby finančného poradenstva neprofesionálnemu klientov, v sektore, v ktorom žiadatel' o udelenie príslušného povolenia zamýšl'a začat' vykonávat' činnost'. Z hl'adiska okamihu uskutočnenia previerky pripravenosti na vykonávanie finančného poradenstva, sme názoru, že jej uskutočnenie je optimálnejšie počas povol'ovacieho konania. A to z dôvodu, že v konaní vo veciach dohl'adu nachádzame procesnoprávnu úpravu postupu pri uskutočňovaní miestnej obhliadky. Uvedené zvyšuje právnu istotu účastníka konania a predvídatel'nost' postup orgánu verejnej správy.

\section{ZÁVER}

Štát vyvíja maximálnu snahu, aby poskytol subjektom finančného trhu čo najväčšiu vol'nost' pri vzniku, zmene alebo zániku právnych vzt’ahov. Zároveň vytvára prostredie vhodné na tvorbu transparentných obchodných záväzkov. V právnom poriadku nachádzame tak verejnoprávne, ako aj súkromnoprávne prostriedky ochrany finančných spotrebitel'ov, vrátane sankcií za porušenie povinností, ustanovených normatívnymi právnymi aktmi. Funkcie v oblasti ochrany finančných spotrebitel'ov plní Národná banka Slovenska. Táto je rovnako orgán dohl'adu nad vykonávaním finančného poradenstva finančným poradcom. Do diapazónu sankcií udel’ovaných danému dohliadanému subjektu finančného trhu patrí aj odobratie povo-

nálnu pripravenost' a schopnost' poskytovat' platobné služby riadne a bezpečne a existenciu funkčného, účinného a obozretne fungujúceho riadiaceho a kontrolného systému žiadatel'a."

28 Porovnaj $\S 55$ ods. 7 v spojení s $§ 55$ ods. 6 zákona o cenných papieroch

29 Porovnaj $\S 18$ zákona o finančnom sprostredkovaní a finančnom poradenstve.

30 Porovnaj $§ 18$ ods. 6 a ods. 7 zákona o finančnom sprostredkovaní a finančnom poradenstve.

31 Pre úplnost' informácií je nutné poznamenat', že v súčasnosti sa v praxi v ústnej časti odbornej skúšky s certifikátom preverujú vedomosti uchádzačov o dosiahnutie najvyššieho stupňa odbornej spôsobilosti aj prostredníctvom prípadovej štúdie, čo považujeme za žiaduce. Porovnaj informácie z webového sídla výlučného organizátora odbornej skúšky s certifikátom, Národnej banky Slovenska https://regfap.nbs.sk/skusky/druhy [cit. 31-12-2019]. 
lenia na vykonávanie činnosti finančného poradcu. Avšak ešte pred použitím najprísnejších sankcií, je vhodné zamysliet' sa nad návrhmi de lege ferenda, u ktorých sme názoru, že by zvýšili kvalitu regulatórneho prostredia, zabezpečujúc vyššiu mieru ochrany klientov.

Prvý návrh de lege ferenda je zameraný na potenciálnu zmenu zákona o finančnom sprostredkovaní a finančnom poradenstve vzt'ahujúci sa na výlučnost' predmetu činnosti, finančného poradenstva, u obchodných spoločností vykonávajúcich finančné poradenstvo. Máme za to, že by išlo o reguláciu, ktorá by zvýšila úroveň ochrany klientov. A to vzhl'adom na skutočnost', že zameranie na finančné poradenstvo by viedlo špecializácii vo väčšej miere, ako je tomu v súčasnosti, kedy sledujeme rozličnost' predmetov činnosti realizovaných obchodnými spoločnost’ami popri tomto druhu podnikania. Druhý návrh de lege ferenda sa zameriava na zavedenie právneho inštitútu predchádzajúceho súhlasu Národnej banky Slovenska ako podmienky na uskutočnenie vybraného okruhu právnych úkonov finančným poradcom. Tretí návrh de lege ferenda sa spája s preverovaním pripravenosti na finančné poradenstvo prostredníctvom miestnej obhliadky počas ktorej by dochádzalo k overeniu personálnej, technickej, ako aj organizačnej stránky vykonávania finančného poradenstva simulovaním poskytovania danej služby neprofesionálnemu klientovi. Obdobnú reguláciu, u ktorej zastávame názor, že zvyšuje úroveň ochrany klientov na finančnom trhu, nachádzame v osobitných právnych predpisoch, ktorými sú zákon o cenných papieroch a zákon o platobných službách.

\section{KLÚČOVÉ SLOVÁ}

finančné poradenstvo, finančný poradca, Národná banka Slovenska, konanie vo veciach dohl'adu, ochrana finančných spotrebitel'ov.

\section{KEY WORDS}

financial advisory, financial advisor, National Bank of Slovakia, proceedings in supervisory matters, protection of financial consumers.

\section{POUŽITÁ LITERATÚRA}

1. BALDWIN, R., CAVE, M., LODGE, M.: Understanding Regulation : Theory, Strategy and Practice. 2. vydanie. Oxford : OXFORD UNIVERSITY PRESS, 2012, 568 s., ISBN 978-0199576098, DOI: 10.1093/acprof:osobl/9780199576081.001.0001.

2. BERISHA, A., GISCH, E., KOBAN, K. a kol.: Haftpflicht-, Rechtsschutzversicherung und Versicherungsvertriebsrecht. Wien : MANZ'sche Verlags- und Universitätsbuchhandlung, 2018, 192 s., ISBN978-3-214-09017-3.

3. BRANDL, E., SARIA, G.: Vom Finanzdienstleistungsassistenten zum Wertpapiervermittler: Anmerkungen zum Ministerialentwurf des BMF 264/ME 24. GP. In: Zeitschrift für Finanzmarktrecht. roč. 6, 2006, č. 3, s. 101- 105.

4. ČUNDERLÍK, L. a kol.: Právo finančného trhu. Bratislava : Wolters Kluwer, 2017, 260 s., ISBN 978-80-8168-753-2.

5. DAVIES, H., GREEN, D.: Global Financial Regulation: The Essential Guide. Cambridge Polity Press, 2008, 326 s., ISBN 978-0745643502.

6. DEWATRIPONT, M., TIROLE, J.: The Prudential Regulation of Banks. Cambridge, MA The MIT Press, 1995, 262 s., ISBN 0-262-04146-4.

7. HEROLD, M.: Finanzberatung gegen Provision oder Honorar : Eine Analyse aus Kundensicht mit Hilfe des Prinzipal-Agent Ansatzes. München, Ravensburg : GRIN Verlag, 2004, 34 s., ISBN 978- 3638699044. 
8. HUSTÁK, Z., ŠOVAR, J., FRANĚK, M., SMUTNÝ, A., CETLOVÁ, K., DOLEŽALOVÁ, D.: Zákon o podnikání na kapitálovém trhu. Komentár. Praha : C. H. Beck, 2012, 1029 s., ISBN 978-80-7400-433-9.

9. KRAVECOVÁ, D.: Finančné sprostredkovanie. Ako podnikat’ legálne. Bratislava : IURIS LIBRI, 2016, 190 s., ISBN 978-80-89635-25-2.

10. LADLER, M., P.: Finanzmarkt und insitutionelle Finanzaufsicht in der EU. Wien : MANZ'sche Verlags- und Universitätsbuchhandlung, 2014, 344 s., ISBN 978-3-21400765-2.

11. MARQUARDT, J., C.: Financial Market Supervision : Some Conceptual Issues. Basle : BANK FOR INTERNATIONAL SETTLEMENTS, 1989, 44 s., ISBN nepridelené.

12. RÝDL, T., BARÁK, J., SAŇA, L., VÝBORNÝ, P.: Zákon o České národní bance. Komentár.

Praha : Wolters Kluwer, 2014, 344 s., ISBN 978-80-7478-622-8.

13. SIDAK, M., DURAČINSKÁ, M. a kol.: Finančné právo. 2. vydanie. Bratislava : C. H. Beck, 2014, 528 s., ISBN 978-80-89603-22-0.

14. SIDAK, M., SLEZÁKOVÁ, A. a kol.: Regulácia a dohl'ad nad činnostou subjektov finančného trhu. Bratislava: Wolters Kluwer, 2014, 240 s., ISBN 978-80-8168-125-7.

\section{KONTAKTNÉ ÚDAJE AUTORA}

JUDr. Andrea Slezáková, LL.M., PhD.

odborná asistentka,

Ekonomická univerzita v Bratislave

Obchodná fakulta, Katedra obchodného práva

Dolnozemská cesta 1

85235 Bratislava

Telefón: +421267291191

E-mail: andrea.slezakova@euba.sk 